\title{
Lots of Bull: Regional Impacts of the 1990s Stock Market Boom
}

\author{
Barney Warf and Joseph C. Cox*
}

\begin{abstract}
Stock markets in the United States experienced a surge of growth throughout the 1990s as an expanding national economy, deregulation, and demographic change produced the longest bull run in history. This paper explores the reasons for this boom. Next, it charts rising employment in securities and commodities firms, emphasizing the dominant role played by New York. Third, it analyzes the local economic impacts of the bull market using regionalized input-output models of the New York, Los Angeles, and Chicago metropolitan areas to estimate regional output, employment, and personal income effects. In the three combined regions over the years 1991-1999, the bull market generated more than $\$ 4.1$ billion in output, two-thirds of which was in the securities industry; 136,000 work-years of employment, primarily in producer services; and $\$ 8.2$ billion in personal income. Geographically, these effects were heavily concentrated in the New York region.
\end{abstract}

\section{INTRODUCTION}

The history of finance has been characterized by a long series of booms and busts, including most obviously the stock market crash of 1929, the surge during the 1980s, the calamitous decline of October 19, 1987, and the steady rise throughout the 1990s. The late twentieth century has seen an unprecedented, and unanticipated, combination of factors that has propelled stock markets to new heights in the longest bull run in history. Since the 1980s, stock markets throughout the U.S. have undergone a sustained increase in trading volumes and prices. Despite occasional setbacks, such as the October 19, 1987, crash, in which the Dow Jones declined by 22 percent (Cox, Preston, and Warf 1991), the total value and volume of stock transactions throughout the U.S. have risen dramatically. On the New York Stock Exchange, for example, the Dow Jones Industrial Average surpassed 10,000, a level unthinkable just a few years ago.

A growing literature on the geography of finance has documented the rapidity of growth in this sector around the world, its highly uneven distribution geographically, the linkages between global flows of capital and world cities, and its global dimensions (Hepworth 1991; Leyshon 1992; Leyshon and Thrift 1992; O'Brien 1992; Clark 1993; Corbridge, Martin, and Thrift 1994; Thrift and Leyshon 1994; Cohen 1998; Martin 1999). This body of work has been instrumental in demonstrating the ways in which geographic landscapes are constructed, and annihilated, through flows of money and in which the political power of the financial community affects policy at the national and local levels. However, most

*Department of Geography, Florida State University, Tallahassee, FL; and Department of Economics, Ryerson Polytechnic University, Toronto, Canada. The authors thank several reviewers for their thoughtful criticisms. 
studies have focused on the international level-explorations of the domestic geography of employment in finance have been relatively few in number.

This paper explores the reasons for and consequences of the 1990s boom. It begins with a review of the fundamental causes, including the rapid rates of economic growth, demographic shifts, deregulation, and technological change. Second, it describes the nature of the boom in detail, including increases in stocks and employment in securities and commodities firms, emphasizing the key role played by the New York metropolis. Third, it offers a methodology for analyzing the regional economic impacts of this phenomenon using input-output analysis, applying this technique to the markets in New York, Los Angeles, and Chicago to estimate regional output, employment, and personal income effects. Fourth, it presents the results of the analysis.

\section{EXPLAINING THE BIG BULL RUN}

Several reasons explain the recent surge in stock prices and trading volumes. These factors represent a contingent conjunction of circumstances that reflect the prominence of finance capital within contemporary capitalism, a relationship in which flows of money rarely directly reflect economic landscapes and local labor markets.

First, the U.S. economy has recently undergone a sustained period of rapid GNP and productivity growth. Following the recession of 1990-1991, a booming economy, low interest rates, and a global glut in raw materials (particularly cheap petroleum) combined to fuel a highly profitable boom. In the wake of the deindustrialization and restructuring of the 1980s, U.S. manufacturing, bolstered by the microelectronics revolution, regained its competitive strength internationally and fueled the demand for investment capital. National productivity growth averaged more than 3 percent annually in the 1990s. Meanwhile, a wave of corporate downsizing and layoffs constrained the growth in labor income. (Note that there is some dispute as to whether current measures of productivity reflect real productivity gains accurately. Some observers point out the discrepancies between rising returns to capital and constant returns to labor as evidence that marginal productivity gains have been exaggerated by official statistics or that the link between the marginal cost and productivity of labor has been annulled). These factors raised corporate earnings and profitability, if not wages, to record levels. Combined with tight Federal Reserve monetary policy, the elimination of the federal government budget deficit, and low inflation rates (indeed, a downward shifting of the Phillips curve), the stage was set for a prolonged increase in stock trades and prices.

Second, widespread technological change followed the microelectronics revolution. In the securities industry, this change allowed for vast increases in the volume of stock trades: trading volume on the New York exchange grew from 12 million shares per day in the 1970s to more than 800 million per day in the 1990s (rising occasionally to more than 1.2 billion per day). As the industry has become 
increasingly capital intensive, obstacles that hindered stock trades in the 1970s have been obliterated and productivity levels have surged. Additionally, the emergence of a global telecommunications network linked national capital markets through the computerized trading of stocks and electronic transfers of funds, thus linking large metropolitan regions in an almost seamless web of finance capital (Warf 1995). The volatility of stock trading rose as hair-trigger computer trading programs allowed fortunes to be made (and lost) by staying microseconds ahead of (or behind) other markets, a trend likely to be accelerated by the rapid growth in on-line trading. Such changes facilitated an influx of foreign capital into U.S. equities markets, which were attractive given the strength of the dollar and the relative stability of the American financial system (Hepworth 1991). Globalization through electronic funds transfer systems also helped to institutionalize volatility in the industry; provide the industry with new leverage in escaping tax provisions, political upheaval, and arbitrage interest rates; and take advantage of favorable currency exchange rates.

Third, the financial industry witnessed widespread deregulation, including the removal of numerous federal and state government restrictions in savings, commercial, and investment banks. In 1980, Congress passed the Depository Institutions Deregulation and Monetary Control Act, and in 1982, the Garn-St. Germain Act, which permitted thrifts to compete directly with commercial banks and eliminated geographic limitations on savings and loan lending (Mayer 1990; Sherrill 1990). For investment bankers, key issues included the abolition of fixed commissions on stock market transactions and the approval of foreign memberships on stock exchanges. Simultaneously, new sources of investment capital, particularly mutual funds and pension funds, for which controls had been abolished, were introduced (Clark 1993). Deregulation unleashed an enormous wave of investordriven demand for investments (most of which found its way into commercial real estate and the stock market), particularly in the form of large investors who buy and sell enormous quantities of stocks, thus enhancing volatility and marginalizing small traders.

Fourth, demographic changes (i.e., the economic behavior of the enormous baby boom generation) accentuated these trends. As they are entering their prime earning and savings years, baby boomers continue to pour resources (primarily via mutual and pension funds) into the stock market as well, viewing it as the best long-term investment. The growth of Internet banking also encouraged numerous small investors to play the market. Accordingly, the proportion of American households that own stock directly has risen to almost 50 percent, and millions more own stock indirectly.

Of course, there is always the chance that this boom is a speculative bubble, one due for a "market correction" followed by a prolonged period of decline. Indeed, long-term increases in price/earnings ratios worry brokers. Yet volatility has become institutionalized within the market, with wild swings in shares and prices the norm. Barring some rapid and unforeseen calamity, the end of the boom 
has yet to appear on the foreseeable horizon. The consequences for regions and the nation, however, are highly uneven.

\section{MEASURING THE BOOM}

The prolonged bull market saw the volume of securities and commodities transactions rise steadily, despite the significant increases in productivity levels that generated vastly higher levels of total output than job numbers alone would indicate. The vast majority ( 76 billion in 1999, or 74 percent) of all stock sales in the U.S. are traded on the New York Stock Exchange (NYSE) (Table 1), which dominates national (and, indeed, international) patterns. The extreme degree of geographic concentration in New York City (particularly Manhattan) reflects that city's long-standing comparative advantage in finance and producer services, particularly the agglomeration economies and access to ancillary services it offers (Mollenkopf and Castells 1991; Sassen 1991; Markusen and Gwiasda 1994). Between mid-1991 and the end of 1999, the total volume of shares traded per day on the NYSE rose from 171 million to 743 million, a 434 percent rise. The total value of stocks traded rose 833 percent, from $\$ 6$ billion to more than $\$ 50$ billion. Following the NYSE, the next three largest exchanges-the American (also located in New York, recently merged with Nasdaq), Chicago, and Pacific (in Los Angeles)-together accounted for an additional 104 million shares in 1999, and grew relatively modestly in comparison to New York. The four exchanges (in three cities) considered here in total account for 848 million out of 1 billion shares (85 percent) traded in the U.S.

\section{TABLE 1}

Sales of Stocks on Major Exchanges (millions of shares)

\begin{tabular}{lrrrrrrrrr}
\hline & 1991 & 1992 & 1993 & 1994 & \multicolumn{1}{c}{1995} & \multicolumn{1}{c}{1996} & 1997 & 1998 & 1999 \\
\hline New York & 171.2 & 228.5 & 297.9 & 320.1 & 388.7 & 452.8 & 549.2 & 639.0 & 742.9 \\
American & 12.3 & 16.2 & 22.3 & 36.3 & 48.6 & 72.4 & 95.2 & 148.8 & 181.5 \\
Chicago & 12.8 & 16.9 & 22.2 & 29.2 & 38.4 & 46.9 & 61.7 & 97.9 & 160.5 \\
Pacific & 8.1 & 10.7 & 14.1 & 18.5 & 20.1 & 28.7 & 37.8 & 51.8 & 73.9 \\
4 Above & 204.4 & 272.3 & 356.4 & 404.1 & 495.9 & 600.8 & 743.9 & 937.5 & 848.1 \\
Total U.S. & 261.2 & 361.3 & 480.8 & 616.8 & 796.6 & $1,096.5$ & $1,349.8$ & $1,688.3$ & $1,848.9$ \\
4 as \% of Total & 78.3 & 88.5 & 87.0 & 89.3 & 87.7 & 87.0 & 85.5 & 85.3 & 84.7 \\
\hline
\end{tabular}

Source: NYSE Fact Book.

While security and commodity brokerages (SIC 62) employment rose nationally from 425,900 in 1991 to 577,700 in 1999, it did not witness the same sharp increases as have stock volumes and prices, a reflection of rising productivity trends in the industry (Table 2). In the New York PMSA, employment in this sector rose from 143,600 in 1991 to 153,900 in 1999, a 7.2 percent increase; in Chicago, it rose from 30,900 to 37,800; and in Los Angeles it grew modestly from 14,200 to 15,200 . However, the three metropolitan regions' share of national employment in this sector declined steadily over time, from 44.3 percent in 1991 to 35.8 percent in 1999. The remainder was dispersed among small exchanges (e.g., Cincinnati, Miami) or among widespread isolated locations throughout the U.S. Given the 
highly uneven geographical distribution of the industry, spatially varying rates in productivity, and the ways in which growth patterns differed among cities, there is little reason to expect that the 1990s boom had similar impacts among different regions. The next step in this analysis offers a methodology for investigating these consequences analytically.

TABLE 2

Security and Commodity Brokers Employment (thousands)

\begin{tabular}{lrrrrrrrrr}
\hline & \multicolumn{1}{c}{1991} & \multicolumn{1}{c}{1992} & 1993 & 1994 & 1995 & 1996 & 1997 & 1998 & 1999 \\
\hline New York & 143.6 & 132.7 & 130.5 & 133.7 & 142.5 & 148.4 & 145.4 & 151.7 & 153.9 \\
Chicago & 30.9 & 30.7 & 31.9 & 32.6 & 34.2 & 36.0 & 35.6 & 36.7 & 37.8 \\
Los Angeles & 14.2 & 14.4 & 13.2 & 14.1 & 14.9 & 14.9 & 13.9 & 14.6 & 15.2 \\
3 Cities' Total & 188.7 & 177.8 & 175.6 & 182.7 & 191.6 & 199.3 & 194.9 & 203.0 & 206.9 \\
& & & & & & & & & \\
U.S. Total & 425.9 & 416.1 & 424.5 & 450.4 & 496.7 & 520.5 & 534.1 & 569.5 & 577.7 \\
3 Cities as \% of U.S. & 44.3 & 42.7 & 41.3 & 40.5 & 38.5 & 38.2 & 36.4 & 35.6 & 35.8 \\
\hline
\end{tabular}

Source: NYSE Fact Book.

\section{METHODOLOGY: ESTIMATING THE IMPACTS}

The analytical approach centered on a 38-sector input-output (I-O) model for three regional economies, the New York City, Chicago, and Los Angeles Metropolitan Statistical Areas, based on the 1992 Bureau of Economic Analysis' RIMS II model. For the securities sector, the regional employee-output ratios and wage value-added coefficients were updated to reflect the conditions in 1999. The total effects of new hirings between June 1991 and December 1999 were analyzed as increases in final demand for services of the securities industry. The period of analysis begins with the end of the 1990-1991 recession and continues until the most recent wage and salary data were available. The increase in final demand during this period was calculated using the I-O relationships between output per employee ( $x / e)$, changes in employment ( $\Delta \mathrm{e}$, using work-years), and changes in final demand $(\Delta f)$. The I-O relation among these three variables is

$$
\Delta \mathrm{f}_{\mathrm{ic}}=\left(1 / \mathrm{m}_{\mathrm{ic}}\right)\left(\mathrm{x}_{\mathrm{ic}} / \mathrm{e}_{\mathrm{ic}}\right) \Delta \mathrm{e}_{\mathrm{ic}},
$$

where $\mathrm{i}$ denotes the securities industry, c indicates the region (New York City, Chicago, or Los Angeles), $\mathrm{m}_{\mathrm{ic}}$ is the I-O multiplier for the securities industry in city $c$, and $\Delta f_{i c}$ is the computed change in final demand for the securities industry in city c consistent with the increase in employment in the time period of analysis. In standard I-O fashion, the model assumes linear production functions, no economies of scale, and infinite elasticities of substitution.

The change in output in each industry of the three regional economies generated by the increase the final demand for securities services was computed using the I-O equation

$$
\Delta \mathrm{x}_{\mathrm{c}}=\mathrm{M}_{\mathrm{c}}^{-1} \Delta \mathrm{f}_{\mathrm{ic}},
$$

where $\Delta \mathbf{x}_{\mathrm{c}}$ is a column vector of output changes in each of the industries in the I$\mathrm{O}$ model of the cth city, i.e., New York, Chicago or Los Angeles, and $\mathrm{M}_{\mathrm{c}}^{-1}$ is the 
Leontief inverse matrix for city c (see Miller and Blair 1985). Column vector $\Delta \mathrm{f}_{\text {ic }}$ indicates the volume of final demand for securities services in city c, in which all elements other than that representing the securities industry is zero.

Total change in employment by industry was estimated by multiplying each vector representing estimated change in output by a series of associated employment/output ratios derived from the RIMS II model. The total number of work-years generated in every industry of each metropolitan area was computed by premultiplying the changes in industry output by a diagonal matrix of outputto-employment coefficients for every industry in each metropolitan area derived from RIMS II, $\mathrm{N}_{\mathrm{c}}$, to form the product, $\mathrm{N}_{\mathrm{c}} \Delta \mathrm{x}_{\mathrm{c}}$. Such an approach assumes that the productivity of new workers in finance equals that of experienced, established brokers, which may not be true in reality.

Changes in employment by industry in each PMSA were decomposed into occupational groups using a rectangular block-diagonal matrix of coefficients, $\mathrm{K}$, which represents the distribution of jobs in each industry among eight occupational groups. Algebraically, the changes in employment by occupation in region $\mathrm{c}$ can be calculated as

$$
\Delta \mathrm{o}_{\mathrm{c}}=\mathrm{K}_{\mathrm{c}} \mathrm{N}_{\mathrm{c}} \Delta \mathrm{x}_{\mathrm{c}},
$$

where $\Delta \mathrm{o}_{\mathrm{c}}$ is a column vector of the change in employment by occupation for each industry in city c. Each block on the main diagonal of $\mathrm{K}_{\mathrm{c}}$ is a column vector of coefficients that allocates employment changes in each industry among occupations in region c.

Last, changes in each industry's total wage and salary income and employment induced by the growth of the major stock exchanges were computed using the changes in output calculated using Equation 2. Data regarding the 1996 distribution of wage and salary income per unit of output by industry in each PMSA were obtained from the Bureau of Economic Analysis' REIS system. Regional variations in output, jobs, and occupations thus reflect the magnitude of growth in the local securities and commodities brokerage industry, the relative capital or labor intensity among industries, and local occupational structures.

\section{EMPIRICAL RESULTS}

The results of this exercise indicate that the nine-year period of growth in securities and commodities employment in New York, Chicago, and Los Angeles generated approximately $\$ 4.2$ billion in total output (Table 3 ). The vast bulk (83 percent) of this increase occurred through the growth of the NYSE, which generated $\$ 3.3$ billion in new output. In comparison, the Chicago exchange generated an increase of only $\$ 708$ million, and the Pacific Exchange in Los Angeles generated a comparatively small $\$ 116$ million increase. The impacts among sectors in the regional economies varied markedly. Among the industries listed in Table 3, the Finance, Insurance, and Real Estate (FIRE) sector witnessed the vast majority of the increased output, including the direct effects, accounting for $\$ 2.4$ billion in 
New York, \$504 million in Chicago, and \$83 million in Los Angeles. FIRE alone accounted for roughly 71 percent of the total impacts when measured by output. Other industries that saw significant increases in output included personal and repair services, communications, publishing, and business services, all of which have extensive forward or backward linkages to FIRE. In contrast, most manufacturing sectors, transportation, and certain services (e.g., health, education, and government) were only marginally affected.

\section{TABLE 3}

Estimated Output Increases from 1991-1999 Stock Market Boom (\$ thousands)

\begin{tabular}{|c|c|c|c|c|}
\hline & New York & Chicago & Los Angeles & Total \\
\hline$\overline{\text { Primary Sectors }}$ & $9,038.079$ & $1,910.865$ & 313.664 & $11,262.6$ \\
\hline Mining and Petroleum & $32,198.559$ & $6,807.852$ & $1,117.544$ & $40,124.0$ \\
\hline Construction & $23,879.612$ & $5,048.835$ & 828.82 & $29,757.3$ \\
\hline Foods \& Tobacco & $14,166.019$ & $2,995.113$ & 491.724 & $17,652.9$ \\
\hline Textiles & $6,826.669$ & $1,443.333$ & 236.988 & $8,507.0$ \\
\hline Wood and Paper & $39,876.796$ & $8,431.227$ & $1,384.112$ & $49,692.1$ \\
\hline Publishing & $82,632.945$ & $17,471.178$ & $2,867.984$ & $102,972.1$ \\
\hline Chemicals & $44,097.346$ & $9,323.556$ & $1,530.504$ & $54,951.4$ \\
\hline Rubber and Plastics & $10,588.213$ & $2,238.648$ & 367.488 & $13,194.3$ \\
\hline Leather and Footwear & 824.561 & 174.381 & 28.536 & $1,027.5$ \\
\hline Stone and Glass & $2,647.929$ & 559.884 & 91.872 & $3,299.7$ \\
\hline Fabricated Metals & $30,196.086$ & $6,384.387$ & $1,048.06$ & $37,628.5$ \\
\hline Electronic Equipment & $18,445.894$ & $3,899.985$ & 640.204 & $22,986.1$ \\
\hline Transport Equipment & $7,636.992$ & $1,614.717$ & 265.06 & $9,516.8$ \\
\hline Scientific Equipment & $6,192.739$ & $1,309.245$ & 214.948 & $7,716.9$ \\
\hline Misc. Manufacturing & $7,006.678$ & $1,481.406$ & 243.136 & $8,731.2$ \\
\hline Land Transport & $17,031.586$ & $3,600.951$ & 591.136 & $21,223.7$ \\
\hline Water Transport & $1,416.907$ & 299.589 & 49.184 & $1,765.7$ \\
\hline Air Transport & $34,902.31$ & 7,379.391 & $1,211.388$ & $43,493.1$ \\
\hline Transport Services & $3,857.255$ & 815.517 & 133.864 & $4,806.6$ \\
\hline Communications & $106,424.078$ & $22,501.365$ & $3,693.672$ & $132,619.1$ \\
\hline Utilities & $35,318.376$ & $7,467.414$ & $1,225.772$ & $44,011.6$ \\
\hline Wholesale/Retail Trade & $32,605.811$ & $6,893.988$ & $1,131.696$ & $40,631.5$ \\
\hline FIRE & $2,385,449.888$ & $504,358.14$ & $82,793.26$ & $2,972,601.3$ \\
\hline Hotels & $27,404.986$ & $5,794.311$ & 951.2 & $34,150.5$ \\
\hline Personal \& Repair Services & $207,008.203$ & $43,767.966$ & $7,184.692$ & $257,960.9$ \\
\hline Business Services & $72,366.104$ & $15,300.462$ & $2,511.632$ & $90,178.2$ \\
\hline Entertainment & $5,439.594$ & $1,150.071$ & 188.848 & $6,778.5$ \\
\hline Health Services & 142.606 & 30.192 & 4.988 & 177.8 \\
\hline Legal Services & $20,397.291$ & $4,312.572$ & 707.832 & $25,417.7$ \\
\hline Education & 732.014 & 154.734 & 25.404 & 912.2 \\
\hline Nonprofit & $3,581.309$ & 757.242 & 124.352 & $4,462.9$ \\
\hline Federal Government & $49,841.136$ & $10,538.007$ & $1,729.908$ & $62,109.1$ \\
\hline State \& Local Government & $6,221.78$ & $1,315.461$ & 215.992 & $7,753.2$ \\
\hline TOTAL & $3,348,014.7$ & $707,874.2$ & $116,201.6$ & $4,172,090.5$ \\
\hline
\end{tabular}

Source: Calculated by authors.

These increases in output generated a variety of jobs (Table 4). Using national output/employment ratios, the increases in regional output attributable to the boom included roughly 136,500 additional work-years, 87 percent of which occurred in New York. In Chicago and Los Angeles, job gains amounted to 15,100 and 2,500 work-years, respectively. As with output, the largest beneficiary among industrial sectors was FIRE, gaining 47,700 work-years in New York, 10,100 in Chicago, and 1,700 in Los Angeles. However, FIRE's share of total employment 
gains was much smaller than its share of total additions to output, a reflection of the industry's increasingly high rates of labor productivity. Other sectors that enjoyed significant increases included construction (13,400 years), personal and repair services $(11,300)$, and, to a much lesser extent, the nonprofit sector and wholesale/retail trade.

TABLE 4

Employment Impacts of 1991-1999 Stock Market Boom (total work-years)

\begin{tabular}{|c|c|c|c|c|}
\hline & New York & Chicago & Los Angeles & Total \\
\hline Primary Sectors & 368 & 26 & 3 & 397 \\
\hline Mining and Petroleum & 2,149 & 49 & 8 & 2,206 \\
\hline Construction & 13,238 & 123 & 21 & 13,382 \\
\hline Foods \& Tobacco & 180 & 24 & 3 & 208 \\
\hline Textiles & 1,338 & 36 & 6 & 1,379 \\
\hline Wood and Paper & 2,116 & 111 & 19 & 2,246 \\
\hline Publishing & 940 & 374 & 61 & 1,376 \\
\hline Chemicals & 968 & 18 & 3 & 990 \\
\hline Rubber and Plastics & 2,033 & 44 & 9 & 2,087 \\
\hline Leather and Footwear & 185 & 6 & 1 & 192 \\
\hline Stone and Glass & 738 & 16 & 2 & 756 \\
\hline Fabricated Metals & 2,240 & 29 & 5 & 2,273 \\
\hline Electronic Equipment & 4,259 & 75 & 12 & 4,346 \\
\hline Transport Equipment & 290 & 18 & 3 & 312 \\
\hline Scientific Equipment & 4,180 & 26 & 3 & 4,209 \\
\hline Misc. Manufacturing & 251 & 33 & 6 & 290 \\
\hline Land Transport & 2,324 & 87 & 14 & 2,425 \\
\hline Water Transport & 94 & 3 & 1 & 98 \\
\hline Air Transport & 455 & 114 & 20 & 589 \\
\hline Transport Services & 118 & 26 & 3 & 147 \\
\hline Communications & 1,907 & 376 & 63 & 2,346 \\
\hline Utilities & 4,075 & 40 & 7 & 4,122 \\
\hline Wholesale/Retail Trade & 5,365 & 181 & 30 & 5,576 \\
\hline FIRE & 47,691 & 10,104 & 1,677 & 59,472 \\
\hline Hotels & 555 & 349 & 58 & 961 \\
\hline Personal \& Repair Services & 9,306 & 1,721 & 287 & 11,313 \\
\hline Business Services & 1,290 & 424 & 58 & 1,772 \\
\hline Entertainment & 191 & 31 & 5 & 227 \\
\hline Health Services & 2,436 & 3 & 1 & 2,440 \\
\hline Legal Services & 197 & 93 & 16 & 306 \\
\hline Education & 78 & 9 & 1 & 88 \\
\hline Nonprofit & 5,288 & 51 & 8 & 5,348 \\
\hline Federal Government & 832 & 498 & 84 & 1,414 \\
\hline State \& Local Government & 1,212 & 31 & 5 & 1,248 \\
\hline TOTAL & 118,888 & 15,148 & 2,504 & 136,540 \\
\hline
\end{tabular}

Source: Calculated by authors.

The occupational distribution of the employment generated by the stock boom varied among the three metropolitan regions and differed from that of the U.S. labor force as a whole (Table 5). In New York, the relative distribution of jobs generated by the stock boom included fewer in managerial and professional occupations than the nation as a whole, but accounted for a significantly larger share of craft workers. The fact that the bulk of new jobs generated by the recent growth of the nation's largest stock market are not professional or managerial should not be surprising. Sassen (1991) notes that "there is a tendency to assume that advanced industries, such as finance, have mostly good, white-collar jobs when in 
fact they also have a significant share of low-paying jobs, from cleaners to stock clerks" (p. 105). In contrast to New York, the distribution of new jobs in Chicago and Los Angeles somewhat approximated that of the country as a whole, with slightly higher numbers of managers but fewer professionals than the national average. Such variations reflect structural differences in local labor markets, labor intensity, regional occupational structure, and interindustry linkages, including interregional linkages as estimated through the deployment of location quotients.

TABLE 5

Occupational Distribution of Work-Years Generated by Stock Market Boom, 1991-1999

\begin{tabular}{lrrrrrrrrr}
\hline & $\begin{array}{r}\text { New } \\
\text { York }\end{array}$ & \multicolumn{1}{c}{$\%$} & \multicolumn{1}{c}{ Chicago } & \multicolumn{1}{c}{$\begin{array}{c}\text { Los } \\
\text { Angeles }\end{array}$} & \multicolumn{1}{c}{$\%$} & Total & \multicolumn{1}{c}{$\%$} & $\begin{array}{r}\text { U of } \\
\text { U.S. }\end{array}$ \\
\hline Managers & 11,425 & 9.6 & 2,148 & 14.2 & 350 & 14.0 & 13,924 & 10.2 & 12.9 \\
Professionals & 11,305 & 9.5 & 1,352 & 8.9 & 223 & 8.9 & 12,880 & 9.4 & 16.9 \\
Sales Reps Brokers & 7,496 & 6.3 & 2,519 & 16.6 & 417 & 16.6 & 10,432 & 7.6 & 4.8 \\
Clerical Workers & 20,707 & 17.4 & 5,654 & 37.3 & 935 & 37.3 & 27,297 & 20.0 & 24.8 \\
Unskilled Sales & 20,589 & 17.3 & 2,057 & 13.6 & 340 & 13.6 & 22,986 & 16.8 & 18.1 \\
Craft Workers & 32,847 & 27.6 & 911 & 6.0 & 155 & 6.2 & 33,914 & 24.8 & 9.1 \\
Operators/Laborers & 14,519 & 12.2 & 506 & 3.3 & 84 & 3.3 & 15,108 & 11.1 & 13.4 \\
TOTAL & 118,888 & 100.0 & 15,148 & 100.0 & 2,504 & 100.0 & 136,540 & 100.0 & 100.0 \\
\hline
\end{tabular}

Source: Calculated by authors.

Finally, the personal income effects of the stock boom were considerable. Combined, the growth of the four exchanges in the three regions generated roughly $\$ 8.2$ billion in wages and salaries (Table 6), the overwhelming majority of which ( $\$ 7.5$ billion, or 91 percent) was to be found in New York. The discrepancy between New York and the other cities reflects not only the larger volume of output generated there, but the higher wages: on average, salaries and wages in New York were 17 percent higher than Chicago and 23 percent higher than Los Angeles. Salary differentials in FIRE were especially pronounced, with New York average wage and salary payments 127 percent above Chicago and 148 percent above Los Angeles (Bureau of Economic Analysis REIS model). As a result of their much smaller securities markets and lower average personal incomes, Chicago saw a relatively small increase of $\$ 602$ million, and Los Angeles a mere $\$ 90$ million. In all three cities, these effects were greatest in the FIRE sector ( $\$ 4.9$ billion), which included the direct effects and paid the highest average income of all industries in the I-O model. Other industries that received significant income boosts included personal and repair services, communications, and the federal government, indicating that the stock boom raised government revenues as well as private sector incomes.

\section{CONCLUDING THOUGHTS}

As the result of the renewed prosperity of the U.S. economy, technological advances, demographic changes, and deregulation, stock markets in the U.S. have witnessed the largest and longest bull run in their history. Although prices and volumes are highly volatile, with occasional downturns, they surged steadily in the 1990s. In the process, the boom has generated significant volumes of output in 
the securities industry and, through networks of linkages, in related sectors as well. The impacts of this event are not inconsiderable. I-O calculations indicate that in the three largest markets in the U.S. combined, the bull market generated more than $\$ 4.1$ billion in output, two-thirds of which were in the securities industry. In employment terms, this translates into roughly 136,500 work-years of employment, although given the highly capital-intensive nature of the securities industry today the bulk of employment gains, unlike output, occurred in other sectors. Most employment changes, however, were in related producer services.

TABLE 6

Personal Income Generated by Stock Boom, 1991-1999 (\$ thousands)

\begin{tabular}{|c|c|c|c|c|}
\hline & New York & Chicago & Los Angeles & Total \\
\hline Primary Sectors & $14,426.2$ & 779.9 & 99.2 & $15,305.4$ \\
\hline Mining and Petroleum & $84,255.8$ & $1,679.4$ & 245.0 & $86,180.2$ \\
\hline Construction & $579,822.2$ & $5,125.5$ & 705.7 & $585,653.5$ \\
\hline Foods \& Tobacco & $6,989.2$ & 649.4 & 86.3 & $7,724.8$ \\
\hline Textiles & $38,807.4$ & 965.5 & 156.0 & $39,929.0$ \\
\hline Wood and Paper & $75,112.9$ & $3,481.4$ & 538.5 & $79,132.8$ \\
\hline Publishing & $32,108.4$ & $11,706.1$ & $1,872.0$ & $45,686.4$ \\
\hline Chemicals & $41,271.1$ & 766.3 & 133.3 & $42,170.7$ \\
\hline Rubber and Plastics & $83,974.7$ & $1,608.5$ & 305.8 & $85,889.0$ \\
\hline Leather and Footwear & $8,185.5$ & 211.5 & 41.5 & $8,438.5$ \\
\hline Stone and Glass & $28,669.0$ & 602.5 & 79.3 & $29,350.8$ \\
\hline Fabricated Metals & $115,767.1$ & $1,315.0$ & 190.0 & $117,272.2$ \\
\hline Electronic Equipment & $181,816.0$ & $2,533.2$ & 369.6 & $184,718.8$ \\
\hline Transport Equipment & $15,606.2$ & 863.2 & 140.0 & $16,609.4$ \\
\hline Scientific Equipment & $221,901.7$ & $1,129.7$ & 136.4 & $223,167.8$ \\
\hline Misc. Manufacturing & $14,148.5$ & $1,595.1$ & 233.2 & $15,976.7$ \\
\hline Land Transport & $124,349.6$ & $4,153.0$ & 622.0 & $129,124.6$ \\
\hline Water Transport & $5,446.4$ & 163.5 & 47.2 & $5,657.0$ \\
\hline Air Transport & $25,743.2$ & $6,053.1$ & 912.3 & $32,708.5$ \\
\hline Transport Services & $6,263.8$ & $1,192.3$ & 166.7 & $7,622.8$ \\
\hline Communications & $81,606.2$ & $15,392.4$ & $2,280.2$ & $99,278.8$ \\
\hline Utilities & $217,185.8$ & $1,866.1$ & 333.4 & $219,385.3$ \\
\hline Wholesale/Retail Trade & $173,297.3$ & $4,903.2$ & 741.9 & $178,942.4$ \\
\hline FIRE & $4,420,911.2$ & $411,246.2$ & $62,565.5$ & $4,894,723.0$ \\
\hline Hotels & $18,530.4$ & $10,498.4$ & $1,612.0$ & $30,640.8$ \\
\hline Personal \& Repair Services & $345,042.8$ & $54,461.7$ & $7,905.0$ & $407,409.5$ \\
\hline Business Services & $78,718.1$ & $22,939.5$ & $2,726.0$ & $104,383.5$ \\
\hline Entertainment & $10,605.8$ & $1,353.2$ & 189.1 & $12,148.1$ \\
\hline Health Services & $124,220.1$ & 135.1 & 41.2 & $124,396.3$ \\
\hline Legal Services & $16,783.1$ & $6,918.4$ & $1,260.8$ & $24,962.2$ \\
\hline Education & $3,852.2$ & 395.0 & 47.8 & $4,295.1$ \\
\hline Nonprofit & $217,444.0$ & $2,069.9$ & 283.4 & $219,797.4$ \\
\hline Federal Government & $48,716.1$ & $21,538.2$ & $3,188.8$ & $73,443.1$ \\
\hline State \& Local Government & $55,285.4$ & $1,314.1$ & 167.7 & $56,767.3$ \\
\hline TOTAL & $7,516,863.3$ & $601,605.6$ & $90,422.8$ & $8,208,891.7$ \\
\hline
\end{tabular}

Source: Calculated by authors.

Geographically, these impacts were highly uneven among the three metropolitan regions examined, which generate the vast majority of the nation's employment and stock trades. By far the largest beneficiary has been the New York area, which greatly exceeds any other in the nation. Indeed, in a city in which securities have displaced commercial banking in employment terms, the bull run 
has had significant effects, directly or indirectly creating more than 118,000 workyears in the 1991-1999 period. However, in New York the stock boom appears, surprisingly, to have augmented the growth of semiskilled, blue collar occupations rather than skilled, white collar ones. Los Angeles saw minimal employment effects, while the Chicago exchange witnessed modest gains. Returns to labor and to firms in terms of wages and salaries and profits, respectively, closely mirrored the spatial distribution of total employment gains but were accentuated by the higher salaries in New York.

Clearly, the soaring stock markets of the 1990s have had nontrivial impacts on local economies. To the extent that the bull run continues in the future, these impacts will persist. However, given the mounting discrepancy between productivity levels and returns to labor, even in well-paid industries such as investment banking, soaring stock trades in the future will generate marginally smaller effects on output, employment, and incomes. For these same reasons, dramatic downturns are also less likely to have widespread effects. In this sense, financial markets appear to have become increasingly detached from much of the rest of the economy, as dramatic changes in stock prices translate into much more modest increases in output, employment, and incomes.

\section{REFERENCES}

Clark, G. "Global Interdependence and Regional Development: Business Linkages and Corporate Governance in a World of Financial Risk." Transactions of the Institute of British Geographers 18 (1993), 309-325.

Cohen, B. The Geography of Money. Ithaca, NY: Cornell University Press, 1998.

Corbridge, S., R. Martin, and N. Thrift, eds. Money, Power and Space. Oxford: Blackwell, 1994.

Cox, J., V. Preston, and B. Warf. "The 1987 Crash and the Spatial Incidence of Employment Changes in the New York Metropolitan Region." Urban Studies 28 (1991), 327-339.

Hepworth, M. "Information Technology and the Global Restructuring of Capital Markets." In S. Brunn and T. Leinbach (eds.) Collapsing Space and Time. London: HarperCollins, 1991.

Leyshon, A. "The Transformation of Regulatory Order: Regulating the Global Economy and Environment." Geoforum 23 (1992), 249-267.

Leyshon, A., and N. Thrift. "Liberalisation and Consolidation: The Single European Market and the Remaking of European Financial Capital." Environment and Planning A 24 (1992), 49-81.

Markusen, A., and V. Gwiasda. "Multipolarity and the Layering of Functions in World Cities: New York City's Struggle to Stay on Top." International Journal of Urban and Regional Research 18 (1994), 167-193.

Martin, R., ed. Money and the Space Economy. New York: Wiley, 1999.

Mayer, M. The Greatest-Ever Bank Robbery: The Collapse of the Savings and Loan Industry. New York: Scribner's, 1990. 
Miller, R., and Blair, R. Input-Output Analysis: Foundations and Extensions. Englewood Cliffs, NJ: Prentice-Hall, 1985.

Mollenkopf, J., and M. Castells. Dual City: Restructuring New York. New York: Russell Sage Foundation, 1991.

O'Brien, R. Global Financial Integration: The End of Geography. Washington, D.C.: Council on Foreign Relations, 1992.

Sassen, S. The Global City: New York, London, Tokyo. Princeton, NJ: Princeton University Press, 1991.

Sherrill, R. "Savings and Loans, Big Banks, and Other Triumphs of Capitalism." Nation, 19 November 1990.

Thrift, N., and A. Leyshon. "A Phantom State? The De-traditionalization of Money, the International Financial System and International Financial Centres." Political Geography 13 (1994), 299-327

Warf, B. "Telecommunications and the Changing Geographies of Knowledge Transmission in the Late 20th Century." Urban Studies 32 (1995), 361-378. 